\title{
Diel and seasonal distribution of perch in Lake Constance: a hydroacoustic study and in situ observations
}

\author{
F. Imbrock, A. Appenzeller and R. Eckmann* \\ Limmological Institute, University of Konstan-, PB 5560, D-78434 Konstan=, Germany.
}

(Received 18 Mar 1995, Accepted 25 November 1995)

\begin{abstract}
A near-shore belt $50 \mathrm{~km}$ in length was surveyed parallel to the shoreline of Lake Constance. central Furope. with a single-beam echosounder five times between July 1993 and February 1994. The specics and age composition of fish in the survey area was investigated by gillnet fishing and SCUBA-diving. In summer. the horzontal distribution of perch was patchy. Population density declinad from cast to west, and highest densities occurred in one shallow bay and close to ports and jetties at steeper shores. During daytine, perch stayed in the sublittoral cone between 3 and $15 \mathrm{~m}$ depth and between 2 and $6 \mathrm{~m}$ above the thermocline. Within this layer age classes were separated spatially the relative number of young-of-the-year perch declined with depth whereas the relative number of adult perch $(2+$ and older $)$ increased with depth. At dusk the fish migrated to the littoral zone. where they spent the night resting on the bottom. In winter, under almost homothermal conditions, perch of all ages were located between the 35 and $70 \mathrm{~m}$ depth contours, where they performed pronounced diel vertical migrations. They rested on. or close 10. the botton during daytime and ascended up to $20 \mathrm{~m}$ below the surface at night. During this season. horizontal distribution of perch was much more homogeneous than in summer
\end{abstract}

Key words: Peral fluviatils: horizontal distribution: vertical distribution: diel migration: hydroacoustics: echo sounding.

\section{INTRODUCTION}

Lake Constance, shared by Austria, Switzerland and Germany, is the second largest, warm-monomictic European pre-alpine lake. It has a surface area of $500 \mathrm{~km}^{2}$, a volume of $47.7 \mathrm{~km}^{3}$. a maximum depth of $252 \mathrm{~m}$ and a mean depth of $100 \mathrm{~m}$. Holomixis occurs in late winter at a temperature of $4^{\circ} \mathrm{C}$. In its natural state. Lake Constance was oligotrophic. Due to anthropogenic eutrophication. the concentration of $\mathrm{PO}_{4}-\mathrm{P}$ during overturn reached a maximum of $87 \mu \mathrm{g} \mathrm{l}^{-1}$ in the late 1970s. Since the beginning of the 1980s, the trophic status of Lake Constance has been decreasing (Geller \& Güde, 1989) and it is currently mesotrophic.

During eutrophication adult perch Perca fluviatilis L. shifted their habitat from the littoral to the sublittoral zone. In parallel, their feeding habits changed from being mainly piscivorous to being planktivorous in summer and benthivorous in winter (Hartmann \& Nümann, 1977). During most of the year juvenile and adult perch seem to be separated spatially (Wang \& Eckmann, 1994). Gillnetting showed that the vertical distribution varies with season, the depth of maximum catch increasing from 6 to $10 \mathrm{~m}$ in summer to more than $40 \mathrm{~m}$ in winter (Hartmann \& Nümann, 1977). Except for this general habitat shift.

*Author to whom correspondence should be addressed. Tel.: +49-7531-882828; fax: +49-7531-883533; email: reiner eckmann $u$ uni-konstanz.de 
little is known about the distribution of perch in this lake. Hartmann (1984) observed increasing commercial yields from west to east. but no data concerning the in situ horizontal distribution have been available so far. The aim of our study was to investigate the temporal and spatial dynamics of perch distribution in Lake Constance for a better understanding of the species' fundamental ecology. In addition, such data provide the necessary basis for abundance estimates and associated management decisions.

\section{MATERIALS AND METHODS}

\section{SAMPLING METHODS}

Echo surveying was made with a single-beam echosounder Simrad EY-M of $70 \mathrm{kHz}$ working frequency equipped with a transducer of $11.2^{\circ}$ beam width, which is described in detail by Jurvelius et al. (1984). The upper $3 \mathrm{~m}$ and the near-bottom layer $(<0.5 \mathrm{~m})$ were not accessible to analysis. Time-varied gain was set to $40 \log \mathrm{R}$. The system was calibrated with a standard copper sphere. The analogue signals were recorded on a tape recorder (SONY TC-D5M stereo cassette recorder). These were digitized and stored on a PC. Data were analysed with special software devcloped at Constance University electronics workshop (Eckmann, 1991).

Fish signals were identified using bottom-set gillnets of 7.10 .14 .28 and $32 \mathrm{~mm}$ mesh size. Net panels were 1.2 to $2 \mathrm{~m}$ deep and 12 to $25 \mathrm{~m}$ long. From July to October. the nets were set between 2 and $20 \mathrm{~m}$ water depth at dusk for periods of $1030 \mathrm{~min}$. In February and March 1994. gillnets were exposed during the night at 35 to $50 \mathrm{~m}$ depth. Total length (L) and wet weight of all fish were measured $(n=472)$ and related to age. which was read from the operculum $(n=109)$.

Light attenuation was determined for each month with a lux meter from stepwisc measurements ( $1 \mathrm{~m}$ intervals), at the same location where diel migrations of perch were investigated (Fig. I). From these data. light intensity for any depth was estimated from surface intensity, assuming an average surface loss of 7\% (Sehanz. 1983). Temperature profiles were measured with a temperature-depth-probe at four sites in the sublittoral zone and at one site in the pelagic zone (Fig. 1). We defined the depth of the thermocline as the depth having the steepest temperature gradient within a $5 \mathrm{~m}$ interval and then selected the $1 \mathrm{~m}$ interval with the greatest temperature difference.

Hydroacoustic investigations were complemented by SCUBA-diving on 18 occasions between April and August 1993 (total diving time $12 \mathrm{~h} 35 \mathrm{~min}$ ). The presence and behaviour of perch were observed between 3 and $30 \mathrm{~m}$ depih at seven sites within the study area (Fig. 1). Each site was visited at least once during the day and once from dusk until dark. Additionally. on one occasion in September. a programmable underwater photo-camera (MINOLTA Dynax 7000i with flashlight NIKONOS SB3) took a series of photographs every $30 \mathrm{~min}$ from dusk until dawn at $4 \mathrm{~m}$ depth.

\section{ECHO SURVEY STRATEGY}

The study was carried out in the near-shore areas of the north-western part of the upper lake's main basin and the eastern part of the fjord-like Uberlinger See. To map the horizontal distribution of perch in this area. we had to consider their diel migrations and their depth distribution. Diel migrations were investigated once a month by surveying a transect of $2 \mathrm{~km}$ length (Fig. 1) every hour from late afternoon until next morning. To evaluate the depth distributions of perch, i.e. the two delimiting depth contours between which $90 \%$ of all fish signals were located, transects perpendicular to the shore were sampled monthly at five to six locations with high fish densities (Fig. 1). Horizontal sampling was then conducted between these depth contours along a $50 \mathrm{~km}$ stretch parallel to the shoreline at a speed of $7.8 \mathrm{~km} \mathrm{~h}^{-1}$. In July. August. September and October 1993 this was done during the day (light intensity $>20 \mathrm{klx}$ ) and in February 1994 at night. 


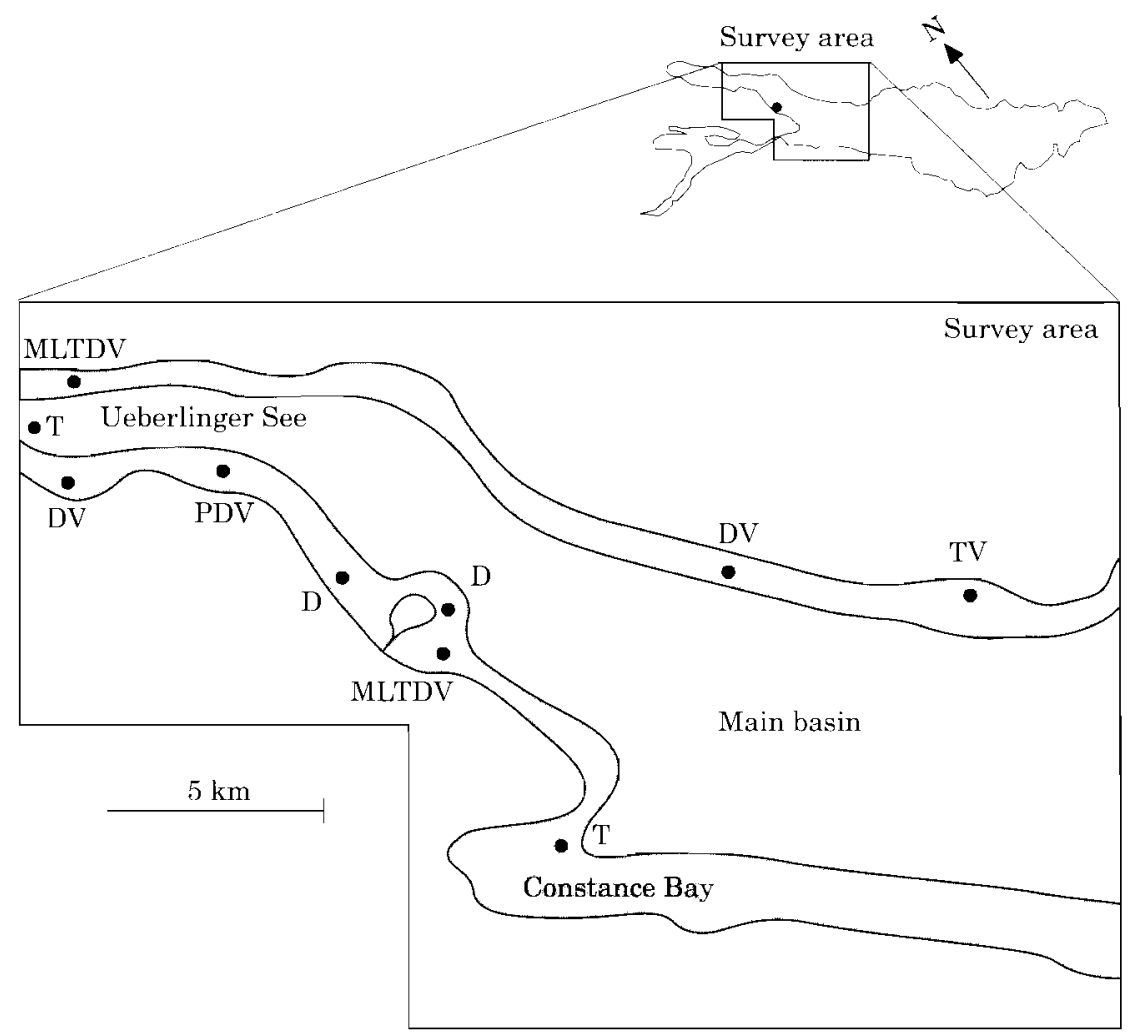

FI⿳. 1. Survey area and the sampling sites in Lake Constance. Grey area: near-shore belt covered by echo sounding parallel to the shoreline. M. transects parallel to the shoreline to investigate the diel migrations of perch: V. transects perpendicular to the shoreline to investigate the depth distribution of perch: L. light profiles; T. temperature profiles; D. diving grounds.

\section{DATA PROCESSING}

After visual inspection of the echograms the shoreline was divided into segments according to changes in fish density. Abundance was calculated for each segment and then assigned to one of four classes: $<100,1001000,100010000,>10000$ fish $^{-1}{ }^{-1}$ surface area. Monthly horizontal distribution maps were constructed from these data. The absolute fish number of each segment was calculated by multiplying fish abundance with surface area. Surface area is the product of segment length and average width of perch schools. Segment length and width of perch schools were mapped by transects parallel and perpendicular to the shoreline and then calculated from the ping rate. the number of pings and the cruising speed. In summer, the school width levelled off at $28 \pm 14 \mathrm{~m}$ for bottom slopes $>12 \%(n=125)$. Thus at all locations with slopes $>12 \%$ where school width had not been measured, we assumed this constant value. In winter. segment width corresponded to the distance between the 35 and $70 \mathrm{~m}$ depth contours.

For subsequent data analysis. the sublittoral zone was divided into two different shore lypes: locations with and without underwater structures in waters deeper than $3 \mathrm{~m}$. Such structures were: wooden or stony ports, jetties, piers, moles or boulder areas. The extension of large ports along the shore was read from the echogram. The extension of segments with narrow structures was set to $100 \mathrm{~m}$.

The shoreline was subdivided into sections of $500 \mathrm{~m}$ length. The percentage of fish contained in each of these sections was counted. The degree of horizontal aggregation was measured by the evenness-index, defined as: 


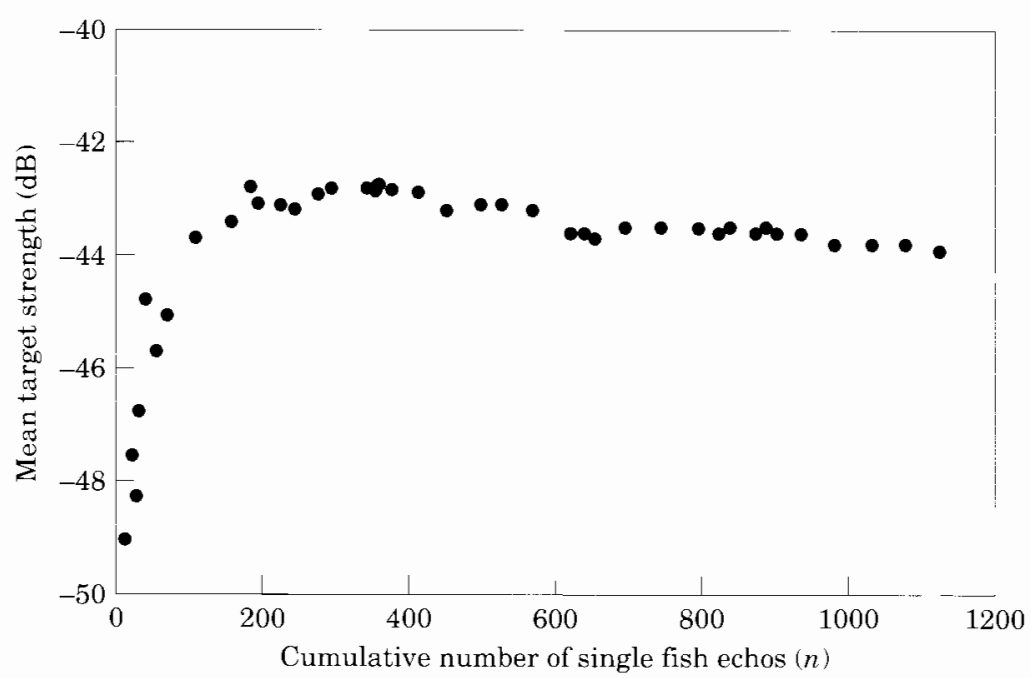

FIG. 2. Target strength estimated by the Craig-Forbes algorithm as a function of the number of single-fish echos.

$$
E=-\sum\left(p_{i}^{*} \ln p_{i}\right)^{*}(\ln Z)^{-1}
$$

where $p_{i}$ is the relative number of fish in section $i$, and $Z$ is the number of sections. $E$ ranges from zero from maximal patchiness (i.e. all fish are concentrated in one section) to I for maximal evenness (i.e. each section contains the same number of fish). To assess the accuracy of abundance estimates by echo sounding, we compared 40 replicated samples for the same school: coefficient of variation was $61 \%$.

\section{TARGET STRENGTH ESTIMATE}

Total echo energy is the sum of echo energy of single fish echos (sfe) and echo energy of schools that are not resolved as single targets. The percentage contribution of echo energy of schools to the total echo energy was used to quantify the intensity of school formation. The target strength $(\mathrm{S})^{*}$ of single fish was estimated by the Craig-Forbes algorithm (Craig \& Forbes. 1969). Provided that sfe $>1000$, this method produces reliable target strength estimates (Jurvelius et al., 1988; Lindem, 1983).

In the present work, however, this condition was often violated because (i) in summer perch formed dense schools during daylight hours and single fish resolution was low, and (ii) to map the distribution of fish with high spatial resolution, it was often necessary to sample short transects of $<500 \mathrm{~m}$ length. Consequently, many sampling units contained far $<1000$ sfe. Therefore, we sampled 40 replicated transects across a typical perch school. Mean S was estimated for increasingly larger sample units by cumulative addition of subtransects. At approximately $>300 \mathrm{sfe}$, S levelled off at $-43.4 \pm 0.4 \mathrm{~dB}$ (Fig. 2). Thus, for transects with $>300$ sfe, the $\mathrm{S}$ distribution was considered reliable. For transects with $<300 \mathrm{sfe}$, the $\mathrm{S}$ distribution of a larger sampling area that comprised the neighbouring transects and that contained $>300$ sfe was used. The estimated $\mathrm{S}$ distribution served to calculate fish number from total echo energy.

In early October, by the end of the growing season, maximum $\mathrm{S}$ was measured on four tethered perch of $10.0 \mathrm{~cm}($ age $0+$ ), $14.5 \mathrm{~cm}$ (age $1+), 22.0 \mathrm{~cm}$ (age $3+$ ) and $25.0 \mathrm{~cm}$ (age $3+$ ) total length. Each fish was exposed for $30 \mathrm{~min}$ in dorsal aspect without any tiit within the sound beam. From about $5000 \mathrm{~S}$-values recorded for each fish, we chose the maximum S. supposing that this corresponds to the echo of the fish staying exactly in the

*It is the journal's policy to avoid the use of multiple letters for mathematical symbols. The commonly used abbreviation for target strength (TS) was. therefore, changed to S, against the explicit will of the authors. 

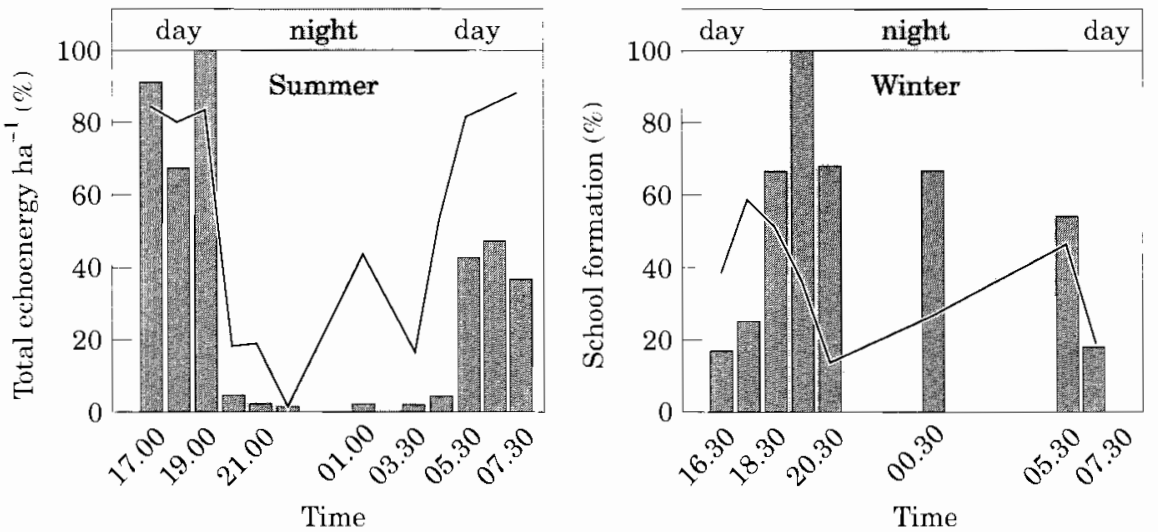

FIG. 3. Diurnal fluctuations of total echoenergy (bars) and intensity of school formation (lines) in summer (left pancl) and winter (right panel). Maximum echoenergy measured during each survey period was set to $100^{\prime \prime} \%$.

centre of the sound beam. This procedure had to be adopted because the exact position of a target in the sound beam of a single-beam sounder cannot be determined. Using this data, we established the following relation $(n=4): S=30 \cdot 2 \log L-74 \cdot 8 . r=0 \cdot 989$ [where $S$ is maximum target strength $(\mathrm{dB})$ and $\mathrm{L}$ is total length $(\mathrm{cm})]$. This $\mathrm{S} /$ length relationship together with the length/age relationship from gillnetting was used to identify the sizes and ages of perch observed by echo sounding. Limited by the resolution of the echo sounder $(-52 \mathrm{~dB})$. perch $<6 \mathrm{~cm}$ could not be detected.

\section{RESULTS}

In summer as well as in winter, perch between 6 and $31 \mathrm{~cm}$ (age $0+$ to $4+$ ) contributed between 93 and $97 \%$ of the total fish biomass and numbers of fish caught by gillnetting in the sublittoral zone of the survey area $(n=472)$. Therefore, we concluded that the signals on the echogram were related almost exclusively to perch. The bycatch comprised eight adult dace Leuciscus leuciscus (L.), 11 adult ruffe Gymnocephalus cernua (L.), one eel Anguilla anguilla (L.) and four adult coregonids Coregonus lavaretus (L.).

\section{DIEL MIGRATIONS AND BEHAVIOUR IN SUMMER AND WINTER}

In summer, perch stayed in dense schools in the sublittoral zone during the day. Ninety per cent of the fish signals were found between the 6 and $30 \mathrm{~m}$ depth contours (5\% and 95\% quantil). Most fish were located at the $10 \mathrm{~m}$ depth contour. Between these depth contours. schools were observed between 3 and $15 \mathrm{~m}$ water depth (5 and 95\% quantil, median: $6 \mathrm{~m}$ ). Intensity of school formation reached very high values of $93 \pm 7 \%(n=79)$. More than half of all schools maintained contact with the lake bottom $(n=434)$. Mean height of schools measured between 2 and $4 \mathrm{~m}$. In some exceptional cases the height of large pelagic schools in Constance Bay reached up to $20 \mathrm{~m}$. Length (extension parallel to the shoreline) and width (extension perpendicular to the shoreline) of schools did not differ significantly $\left(n_{1}=229\right.$ and $n_{2}=163$, respectively). School diameter fluctuated between 20 and $30 \mathrm{~m}$. At dusk and light intensities of $<100 \mathrm{~lx}$ in $8 \mathrm{~m}$ depth, echo energy ha ${ }^{-1}$ and intensity of school formation 


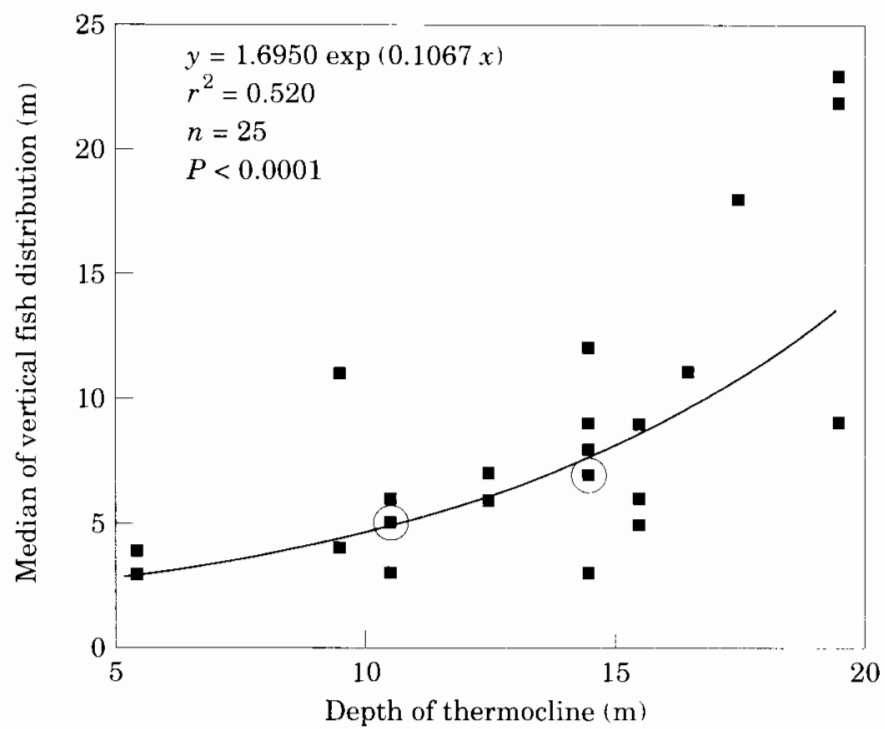

Fig. 4. Regression of the median vertical distribution of perch during day in summer and the depth of the thermocline.

declined dramatically. These values remained low at night and increased again at dawn [Fig. 3 (left panel)]. Direct observations by SCLBA-diving showed that by day perch were encountered from $1-30 \mathrm{~m}$ depth, but by night, only few individuals were seen deeper than $5 \mathrm{~m}$. Further, at dusk, dense perch schools migrated inshore close to the bottom. In the littoral zone schools dispersed and the fish rested on the bottom during darkness. At dawn they showed a reverse migration to the sublittoral zone. Observations with the programmable underwater camera at $4 \mathrm{~m}$ water depth provided additional evidence for the fishes nocturnal inactivity. Up to 47 perch per photograph were counted at dusk and dawn, suggesting high fish activity. But not a single fish was seen on 19 photographs during darkness.

In winter perch were detected by echo sounding between the 35 and $70 \mathrm{~m}$ depth contours. They spent the day close to the bottom, but at dusk they ascended into the pelagic region up to $20 \mathrm{~m}$ below the surface. During the night they were evenly dispersed within the water column. The nocturnal increase of echoenergy [Fig. 3 (right panel)] is due to this diel migration.

\section{INFLUENCE OF WATER TEMPERATURE ON THE VERTICAL DISTRIBUTION OF PERCH IN SUMMER}

Echo sounding data showed that between July and September, perch of all ages were present within the epilimnetic zone at water temperatures between 12.9 and $18.6^{\circ} \mathrm{C}$. In October they stayed in waters of $10.8-13^{\circ} \mathrm{C}$. These temperatures represent the median depths of the fishes' vertical distribution $(n=25)$. The median vertical distribution of perch was regressed on the depth of the thermocline by an exponential model (Fig. 4). From July until mid-October vertical distribution of perch and depth of the thermocline were significantly correlated. The centre of the fish schools was located between 2 and $6 \mathrm{~m}$ above the thermocline throughout the stratification period. 


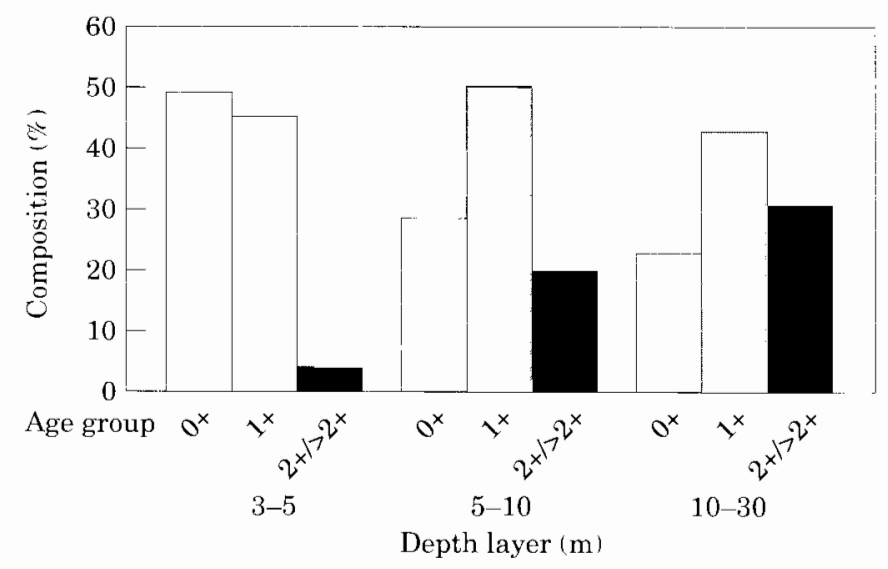

Fici. 5. Percentage composition by age of perch in three epilimnetic layers.

\section{SPATIAL SEGREGATION OF DIFFERENT SIZE CLASSES IN SUMMER}

From July until mid-October different size classes of perch detected by echo sounding were separated spatially. From 3 to $30 \mathrm{~m}$ water depth, the relative number of young-of-the-year perch declined from 49.6 to $24.0 \%$, whereas the relative number of adults ( $2+$ and older) increased from 4.6 to $31.7 \%$ (Fig. 5). The relative number of $1+$ perch was about $50 \%$ in all three strata (range $44 \cdot 3-50 \cdot 6 \%)$. In the water layer closest to the surface $(3-5 \mathrm{~m})$ mean $\mathrm{S}$ was significantly lower than in the two deeper layers, while between those two layers mean S was not significantly different (Lord Test) (Lozán, 1992).

\section{HORIZONTAL DISTRIBUTION OF PERCH IN THE SURVEY AREA}

From July until mid-October, horizontal distribution patterns of perch were very similar [Fig. 6(a)]. Summer distribution was characterized by pronounced patchiness (evenness-index between 0.456 and 0.828). Abundances varied between 0 and 140000 fish ha ${ }^{-1}$. Between 86 and $97 \%$ of all perch were concentrated in areas with fish densities $>1000$ fish ha I. These areas contributed only between 15 and $45^{\prime \prime} \%$ to the length of the surveyed shore line [Fig. 7(a)]. Highest fish densities were always encountered close to ports and jetties. These sublittoral underwater structures were characterized by fish densities 8-65 times higher than shores without such structures (Table I). Constance Bay represented the only exception to this rule. In this region fish abundances reached high levels even further away from the shore.

In October, perch of all ages started to migrate towards the profundal zone. In February 1994 they were dispersed between the 35 and $70 \mathrm{~m}$ depth contours [Fig. 6(b)]. In contrast to summer, the horizontal distribution of perch was very homogeneous in winter (evenness-index between 0.835 and 0.928 ). Because the area that was inhabited by perch in winter ( 2000 ha) was about 10 times greater than in summer (200 ha). winter abundance was much lower. never exceeding 1000 individuals ha ${ }^{-1}$. Ninety-eight per cent of all perch were detected at sites with abundances between 100 and 1000 fish ha ${ }^{-1}$. These sites comprised two-thirds of the surveyed shoreline [Fig. 7(b)]. 

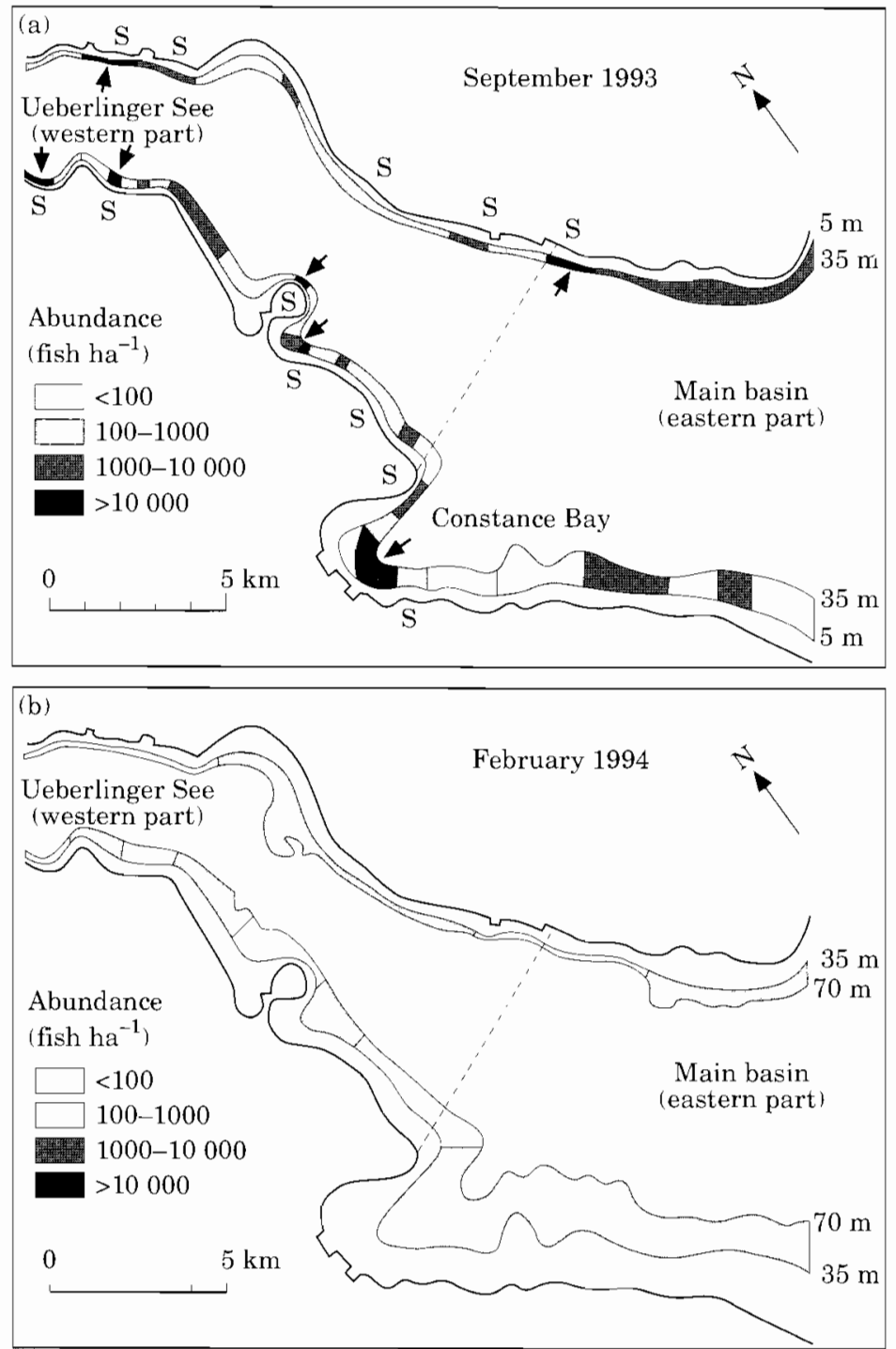

Fig. 6. Typical horizontal distribution of Perce furiatilis in Lake Constance in (a) summer and in (b) winter. The dotted line divides the sludy area in a western and an eastern part. Arrows indicate sites with fish densities $>10000$ fish ha $\quad$. S indicates sublittoral underwater structures.

In both summer and winter, fish numbers per $\mathrm{km}$ shoreline were up to four times higher in the eastern part (main basin) than in the western part of Lake Constance (Überlinger See) (Table II). Only in October were more perch per km shoreline present in the western part.

\section{DISCUSSION}

\section{TIMING OF HYDROACOUSTIC INVESTIGATIONS ON PERCH}

The present study describes the diel and seasonal changes in behaviour of perch in Lake Constance. They were of fundamental interest to define best 


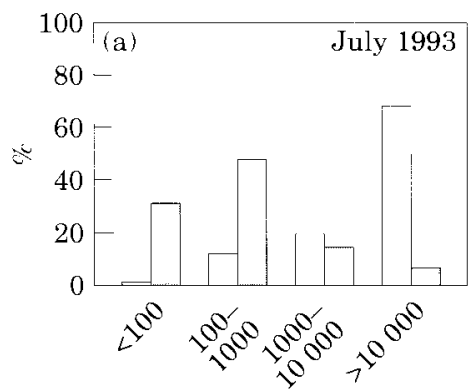

Abundance classes (fish ha ${ }^{-1}$ )

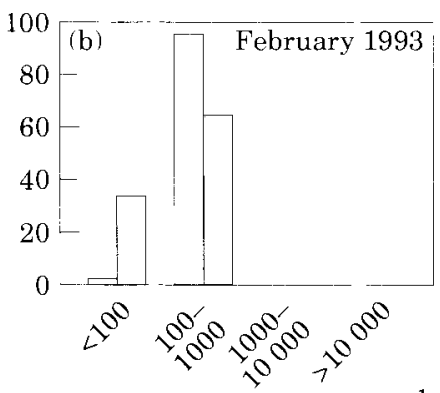

Abundance classes (fish ha ${ }^{-1}$ )

FIG. 7. Patchiness in distribution in (a) summer and (b) winter. Each shore segment is assigned to one of four abundance classes. - - Relative number of perch at sites belonging to the corresponding abundance class. $\square$. Relative length of the shoreline covered by the corresponding abundance class.

TABLE 1. Mean perch abundances (fish ha ${ }^{-1}$ ) \pm S.E. at sites with and without underwater structures in the sublittoral of the survey area except Constance Bay

\begin{tabular}{|c|c|c|c|}
\hline Month & $\begin{array}{l}\text { With structure } \\
(\text { mean } \pm \text { S.E. })\end{array}$ & $\begin{array}{l}\text { Without structure } \\
(\text { mean } \pm \text { S.E. })\end{array}$ & Factor \\
\hline Jul. & $\begin{array}{c}8097 \pm 2263 \\
(n=12)\end{array}$ & $\begin{array}{c}864 \pm 209 \\
(n=54)\end{array}$ & $9 \cdot 4$ \\
\hline Aug. & $\begin{array}{c}22533 \pm 9151 \\
(n=12)\end{array}$ & $\begin{array}{c}838 \pm 104 \\
(n=84)\end{array}$ & $26 \cdot 9$ \\
\hline Sep. & $\begin{array}{c}16347 \pm 4129 \\
(n=12)\end{array}$ & $\begin{array}{c}2016 \pm 341 \\
(n=80)\end{array}$ & $8 \cdot 1$ \\
\hline Oet. & $\begin{array}{c}20438 \pm 12279 \\
(n=12)\end{array}$ & $\begin{array}{l}314 \pm 50 \\
(n=95)\end{array}$ & $65 \cdot 1$ \\
\hline
\end{tabular}

\footnotetext{
At sites with underwater structures, fish density was measured directly in the school. At sites without underwater structures, abundance measurements are based on segments of $500 \mathrm{~m}$ length.
}

conditions for hydroacoustic investigations: since perch resting on the bottom or in shallow waters are not accessible by echo sounding, surveys should be carried out in summer in daylight and in winter at night.

In summer, at evening twilight, perch of all ages moved to shallow littoral areas where they dispersed and settled down until dawn. The transition from daytime activity to nocturnal inactivity has already been described by Hasler \& Villemonte (1953). While changing to the nocturnal resting mode, the fish show a decreasing sensitivity to visual and mechanical stimuli (Helfman. 1979). Nocturnal quiescence might be a predator avoidance behaviour that reduces predation risk from nocturnally active enemies that perceive prey by mechanical stimuli. Young-of-the-year perch, however, are still vulnerable to predation by European eel Anguilla anguilla (L.), which is the most important predator in the shallow littoral zone of Lake Constance (Radke, pers. comm.).

Until now, the pronounced diel migrations in winter have not been described elsewhere in the literature. They seem to be characteristic for perch of Lake 
TABLE II. Number of perch per $\mathrm{km}$ shoreline ( \pm S.E.) in the western and eastern part of Lake Constance

\begin{tabular}{|c|c|c|c|}
\hline Month & $\begin{array}{l}\text { Western part } \\
(\text { mean } \pm \text { S.E. })\end{array}$ & $\begin{array}{l}\text { Eastern part } \\
(\text { mean } \pm \text { S.E.) }\end{array}$ & $\begin{array}{l}\text { Factor } \\
\text { (east/west) }\end{array}$ \\
\hline Jul. & $\begin{array}{c}3772 \pm 1232 \\
(n=50)\end{array}$ & $\begin{array}{c}12947 \pm 5824 \\
(n=28)\end{array}$ & $3 \cdot 4$ \\
\hline Aug. & $\begin{array}{c}5923 \pm 1856 \\
(n=60)\end{array}$ & $\begin{array}{c}8129 \pm 2227 \\
(n=43)\end{array}$ & $1 \cdot 4$ \\
\hline Sep. & $\begin{array}{c}9026 \pm 2811 \\
(n=58)\end{array}$ & $\begin{array}{c}38449 \pm 17132 \\
(n=47)\end{array}$ & $4 \cdot 3$ \\
\hline Oct. & $\begin{array}{c}6525 \pm 3644 \\
(n=58)\end{array}$ & $\begin{array}{c}1323 \pm \\
(n=67)\end{array}$ & $0 \cdot 2$ \\
\hline Feb. & $\begin{array}{c}4589 \pm 949 \\
(n=63)\end{array}$ & $\begin{array}{c}17865 \pm 2207 \\
(n=53)\end{array}$ & $3 \cdot 9$ \\
\hline
\end{tabular}

Abundance measurements are based on segments of $500 \mathrm{~m}$ length.

Constance and are the subject of further investigations (Eckmann. unpublished data).

\section{VERTICAL DISTRIBUTION OF PERCH IN SUMMER}

In summer the vertical distribution of perch schools was correlated to the depth of the thermocline. Throughout the growing season perch were present by day in an epilimnetic layer between 3 and $15 \mathrm{~m}$ depth. approximately $5 \mathrm{~m}$ above the thermocline. Accordingly, Hartmann \& Löfler (1978) caught perch mainly between 6 and $10 \mathrm{~m}$ depth. Preferred temperature in laboratory and field distribution studies covers a wide range from c. 13 to $30^{\circ} \mathrm{C}$ (Hokanson. 1977). In Lake Constance, perch lived in relatively cold waters of $13-19^{\circ} \mathrm{C}$. Here, they occupied a temperature niche intermediate between cyprinids and coregonids and they were located vertically between these two species (Hartmann \& Löfler, 1978). Considering the fact that the epilimnetic water is oxygen saturated. it is unlikely that the vertical distribution of perch in the nearshore areas of Lake Constance is affected by oxygen gradients.

\section{SPATIAL SEGREGATION OF DIFFERENT SIZE CLASSES OF PERCH}

Our hydroacoustic data showed that different size classes of perch are separated spatially in summer. Young-of-the-year fish dominated in the littoral zone. whereas adults stayed mainly in the sublittoral. This segregation was interpreted as avoidance of cannibalism by Wang \& Eckmann (1994). They found that the rate of cannibalism increased when juveniles and adults cooccurred in the sublittoral in late October. The proximate reason for this separation might be that young perch generally select higher temperatures (McCauley \& Read. 1973; Hokanson. 1977) and thus the upper strata of the water column (Ferguson, 1958), or that they exploit different food resources.

\section{HORIZONTAL DISTRIBUTION IN SUMMER}

During the summer months the shallow Constance Bay was always inhabited by more than $10 \%$ of all fish detected in the survey area. In Lake Kinneret. 
Israel, both fish and zooplankton were concentrated in zones where temperature and oxygen gradients were highest (Kalikhman et al., 1992). In Lake Constance, these large pelagic perch schools next to the lake's outflow might be related to particular oxygen, temperature or food regimes as well. These parameters, however. were not evaluated in detail in this study. As Constance Bay belongs to the eastern part of the survey area, these fish schools contribute finally to the higher numbers of perch per $\mathrm{km}$ shoreline in the lake's main basin. But on a whole lake basis as well, Hartmann (1984) reported increasing yields from west to east. This might be due to the higher proportion of shallow bays in the eastern part. which are morphologically similar to Constance Bay. Large numbers of perch have also been reported for the shallow Bregenz Bay at the eastern end of the lake (Dahm et al. . 1985).

During the growing season perch aggregated preferentially close to sublittoral underwater structures at steeper shores in the north-western part of the lake. Large sublittoral areas without such structures were inhabited by few perch only. Echo surveys were conducted during daylight in summer, when perch formed dense schools, and during night in winter, when perch floated as single fish in the water column. The different degree of aggregation by day and night, however, is not the main reason for the seasonal changes of patchiness.

The apparent preference of perch for underwater structures at steeper shores in the north-western part of the lake has already been noted by fishermen and Scheffelt \& Schweizer (1926). Such structures might serve as orientation marks or they provide shaded hiding places or refuge from predators. We did not evaluate the possibility that zooplankton might be more abundant at these sites.

Our observations during summer months showed that the heterogeneous distribution of perch was persistent and that the fish did not change sites or preferences. This is an indication for a possible site and school fidelity of perch as described for other lakes (Chikhova, 1973: Craig, 1974: Helfman, 1984). In our study, the furthest displacement of perch aggregations occurred along expanded boulder areas. But displacement was always $<1 \mathrm{~km}$ from one month to another. In Lac Saint-Louis, Quebec, average distances travelled by marked yellow perch ranged from 1.9 to $3.9 \mathrm{~km}$ (Fortin \& Magnin. 1972; cited by Thorpe, 1977). Aalto \& Newsome (1990) support the hypothesis that perch in Lochaber Lake return to their natal location to spawn. If perch in Lake Constance form subpopulations, or even demes that exhibit reproductive isolation, should be the subject of further investigations.

\section{HORIZONTAL DISTRIBUTION IN WINTER}

With the beginning of autumnal mixing, perch started to migrate towards the profundal zone. This seasonal migration has been observed also in other lakes (Allen, 1935; Ferguson, 1958; Forney, 1971). In Lake Constance, the sites at which perch overwinter are not characterized by higher benthos abundances (Hartmann \& Probst, 1995). We suggest that overwintering sites are selected mainly according to lake morphology, because we observed overwintering perch only on slightly declining but not on steeply sloping bottoms. The gradual return to the littoral zone started in winter and ended in late spring when perch spawn in shallow waters. This seasonal migration might ensure gonad growth and 
gamete maturity that requires temperatures below $10^{\circ} \mathrm{C}$. Optimal conditions for maturation occurred, when fish were exposed to $6^{\circ} \mathrm{C}$ or lower for 185 days (Hokanson. 1977). This corresponds to the winter period between late October and late April.

We thank P. Fischer and A. Sulger for their assistance in all field operations. This study was supported by Deutsche Forschungsgemeinschaft within the special collaborative program (SFB 248), Cycling of Matter in Lake Constance. The manuscript was prepared while F.J. was a visiting scicntist at the Institute of Freshwater and Fish Ecology in Berlin.

\section{References}

Aalto. S. K. \& Newsome, G. E. (1990). Additional evidence supporting demic behaviour of a yellow perch (Perca flavescens) population. Canetdian Joumal of Fisheries and Aquatic Sciences 47, 19591962.

Allen. K. R. (1935). The food and migration of the perch (Perca fhuratilis) in Windermere. Journal of Animal Ecolog! 4, 264273.

Chikhova, V. M. (1973). Local populations of perch (Perca fluriatilis L.) in Kuybyshev Reservoir. Journal of Ichthyology 13, 491-496.

Craig. J. F. (1974). Population dynamics of perch, Perca fluviatilis L., in Slapton Ley, Devon. I. Trapping behaviour. reproduction. migration, population estimates, mortality and food. Freshwater Biology 4, 417-431.

Craig. R. E. \& Forbes. S. T. (1969). Design of a sonar for fish counting. Fiskeridirektoratets skrifter Serie, Havundersokelse'r 15, 210-219.

Dahm. E., Hartmann. J., Lindem. T. \& Löffler, H. (1985). EIFAC experiments on pelagic fish stock assessments by acoustic methods in Lake Constance. EIFAC Occasional Paper 15, 114.

Eckmann. R. (1991). A hydroacoustic study of the pelagic spawning behaviour of whitefish (Corcgonus lavaretus) in Lake Constance. Conadian Journal of Fisheries and Aquatic Sciences 48, 995-1002.

Ferguson, R. G. (1958). The preferred temperature of fish and their midsummer distribution in temperate lakes and streams. Journal of the Fisheries Research Board of Comada 15, 607-624.

Forncy, J. L. (1971). Development of dominant year classes in a yellow perch population. Transactions of the American Fisheries Socictl 100, 739-749.

Geller. W. \& Güde, H. (1989). Lakc Constance - the largest German lake. In Limmology" in the Federal Republic of Germany (Lampert. W. \& Rothhaupt. K.-O., eds). pp. 9-17. Kiel: Carius.

Hartmann, J. (1984). Zur gebietsweisen Verteilung der Fische im Bodensee. Österreichs Fischerei 37, 231-233.

Hartmann, J. \& Löfler. H. (1978). Saisonale bodennahe Verteilung von Fischen im cutrophierten Bodensee. Archiv für Hydrohiologie 83, 69-79.

Hartmann, J. \& Nümann. W. (1977). Percids of Lake Constance, a lake undergoing eutrophication. Journal of the Fisheries Research Bocrd of Canada 34, 1670-1677.

Hartmann, J. \& Probst, L. (1995). Divergent distributions of prey and predator, a fishing effect? Aquatic Sciences 57, 106118.

Hasler, A. D. \& Villemonte, J. R. (1953). Observations on the daily movements of fishes. Science 118, 321-322.

Helfman, G. S. (1979). Twilight activities of yellow perch, Perca flavescens. Journal of the Fisheries Research Board of Canada 36, 173-179.

Helfman, G. S. (1984). School fidelity in fishes: the yellow perch pattern. Animal Behaviour 32, 663-672.

Hokanson, K. E. F. (1977). Temperature requirements of some percids and adaptions to the seasonal temperature cycle. Journal of the Fisheries Research Board of Canada 34, 1524-1550. 
Jurvelius, J., Lindem. T. \& Louhimo, J. (1984). The number of pelagic fish in Lake Paasivesi. Finland, monitored by hydroacoustic methods. Fisheries Research 2 , $273-283$.

Jurvelius, J., Lindem, T. \& Heikkinen, T. (1988). The size of a vendace, Coregonus albula L., stock in a deep lake basin monitored by hydroacoustic methods. Journal of Fish Biology 32, 679-687.

Kalikhman, P., Walline, P. \& Gophen, M. (1992). Simultaneous patterns of temperature, oxygen, zooplankton and fish distribution in Lake Kinneret, Israel. Freshwater Biology 28, 337-347.

Lindem, T. (1983). Success with conventional in situ determinations of fish target strength. FAO Fisheries Report 300, 104-111.

Lozán, J. L. (1992). Angewandte Statistik für Naturwissenschaftler. Berlin: Paul Parey.

McCauley, R. W. \& Read. L. A. A. (1973). Temperature selection by juvenile and adult yellow perch (Perca flavescens) acclimated to $24^{\circ} \mathrm{C}$. Journal of the Fisheries Research Board of Canada 30, 1253-1255.

Scheffelt. F. \& Schweizer, W. (1926). Fische und Fischerei im Bodensee. Stuttgart: Enke.

Schanz. F. (1983). Light conditions in Lake Zürich, 1980/81. Part II: Surface effects. Archiv für Hydrobiologie 97, 501-508.

Thorpe, J. E. (1977). Morphology, physiology, behavior and ecology of Perca fluviatilis L. and P. flavescens Mitchill. Journal of the Fisheries Research Board of Canada 34, $1504-1514$.

Wang, N. \& Eckmann, R. (1994). Distribution of perch (Perca fluviatilis L.) during their first year of life in Lake Constance. Hydrobiologia 277, 135-143. 